\title{
The Characteristics of West Season Wind and Wave as well as Their Impacts on Ferry Cruise in The Kalianget-Kangean Cruise Route, Madura, Indonesia
}

\author{
Viv Djanat Prasita*, Lukman Aulia Zati and Supriyatno Widagdo \\ Department of Oceanography, Hang Tuah Surabaya, Jalan Arif Rahman Hakim 150, Sukolilo Surabaya, \\ Indonesia
}

\begin{abstract}
The wind and wave conditions in the waters of the Kalianget-Kangean cruise route in the west season are relatively high so that these winds and waves can have a dangerous impact on that cruise route. The aim of this research was to analyze the characteristics of wind speed and wave height over a 10 year period (2008-2017), as well as to evaluate the weekly patterns for three months (December 2017-February 2018). These time stamps represent the west season in waters at Kalianget-Kangean route, and to identify the impact of winds and wave on this path. The method used in this research is descriptive statistical analysis to obtain the mean and maximum values of wind speed and wave height. Wind and wave patterns were analyzed by WRPlot and continued with mapping of wind and wave patterns in the waters of Kalianget-

ARTICLE INFO

Article history:

Received: 23 December 2021

Accepted: 16 April 2021

Published: 19 July 2021

DOI: https://doi.org/10.47836/pjst.29.3.16

E-mail addresses:

viv.djanat@hangtuah.ac.id (Viv Djanat Prasita)

lukman.zati10@gmail.com (Lukman Aulia Zati)

supriyatno.widagdo@hangtuah.ac.id (Supriyatno Widagdo)

*Corresponding author

Kangean and its surroundings. The data used was obtained from the Meteorology, Climatology and Geophysics Agency. The results show wind and wave characteristics with two peaks formed regularly between 2008-2017, marking the west and east monsoons. In addition, the wind speed and wave height were generally below the danger threshold, ie $<10$ knots and $<2 \mathrm{~m}$, respectively. However, there are exceptions in the west season, especially at the peak in January, where the forces are strengthened with a steady blowing direction. The
\end{abstract}


maximum wind speed reaches and wave height reaches 29 knots and $6.7 \mathrm{~m}$, respectively. The weekly conditions for both parameters from December 2017 to February 2018 were relatively safe, for sailing. Moreover, January 23-29, 2018 featured extreme conditions estimated as dangerous for cruise due to the respective maximum values of 25 knots and $3.8 \mathrm{~m}$ recorded. The channel is comparably safe, except during the western season time in December, January, February, characterized by wind speeds and wave height exceeding 21 knots and $2.5 \mathrm{~m}$, correspondingly.

Keywords: Cruise security, wave height, west monsoon, wind speed

\section{INTRODUCTION}

Indonesia's geographical condition comprises thousands of islands, with the sea serving as a noticeable connecting factor. This makes sea transportation, especially inter-island crossings an important aspect in marine resource utility and is expected to drive the wheels of the archipelago's maritime development. Moreover, some of the essential considerations in crossings between islands or countries include the weather-oceanography factors, particularly in the form of wind, current and wave conditions. Also, it is important to assess the physical characteristics of sea surfaces, to provide a safe and comfortable cruise database, especially in busy regular channels (Aji, 2015). This evaluation is required due to the increasingly intensive global climate change, as observed with the relatively erratic weather conditions in Indonesia. Furthermore, the volatility has some negative impacts, including rainy seasons with rainfall above normal; the emergence of strong winds with the potential to become whirlwinds, accompanied by heavy rain and lightning; and high sea waves. These undesirable effects have been observed in Sumenep Regency, in the district at the eastern tip of Madura Island, featuring a rainy season extending from January 2008.

In addition, the wave height in the west season could be between $2-4.5$ meters (Nugraha et al., 2013). Based on estimates from the Class II Maritime Meteorological Station of Tanjung Perak Surabaya, the wave height in Kangean waters and its surroundings was in the range of 1 meter to 2.25 meters on Friday (1/3/2020) and 1.5 meters to 3.5 meters on Saturday (1/3/2020) so that KMP Dharma Bahari Sumekar I belonging to PT Sumekar, which was scheduled to sail from Kalianget Port to Kangean Island, Sumenep, Madura, East Java, would not operate due to bad weather (Slamet, 2020).

Moreover, Madura waters as a part of the Java Sea Oceanic region are on an ideal path for the ongoing monsoonal processes, known to influence the weather conditions. The west season is monsoonally attributed as the period with the strongest winds.

Conversely, Kangean Island is a great tourist location with coral reefs and natural conditions considered as good (Arisandi et al., 2018). The coral reef area expanding up to 41,849 hectares, with details in the Sapeken District and Sepanjang Island reaching 30,786 
and 11,063.7 hectares, respectively, while the mangroves cover about 4,227.8 hectares (Muhsoni, 2015).

Previous study has also shown the high suitability of Kangean island for nautical tourism (Rini et al., 2015). Therefore, it is important to have in-depth knowledge of the weather and climate conditions, being an intrinsic component of the vacation experience, and is required to further motivate tourists (Scotta \& Lemieux, 2010). The wind is one of the most important climate parameters, known to provide comfort and capable of generating harmful waves to visitors and the environment. The beaufort wind scale is frequently used as an indicator standard to assess wind and waves (Sandino et al., 2016).

Moreover, this cruise route is important for the movement of the economic wheels of the two regions. Therefore, delays in shipping can affect the socio-economic life of the local community. For the local community, marine resources in the Kangean Sumenep archipelago are a good asset to develop (Faqih, 2014).

Therefore, the objectives of this research were to analyze the wind and wave characteristics over 10 years (2008-2017), patterns for 3 months (December 2017-February 2018 ) as a representation of the west season and identify dangerous forms in this route.

\section{MATERIALS AND METHODS}

The data used in this study include 2 periods, a long period and a short period. Long period data is from 2008 - 2017 to elaborate seasons that have high waves and wind speeds that have the potential to endanger the Kalianget-Kangean route. Short period data was obtained for 3 months, December 2017-February 2018 as representative of the western season which during the 10-year period was the most dangerous season and at the same time became the up-to-date period when this research was conducted. From these data, statistical data processing is carried out in the form of determining the average wind speed and wave height and their maximum value. The minimum value is not used because the hazard aspect only refers to the maximum value.

The materials needed in this research include oceanographic data obtained from the Meteorology Climatology and Geophysics Agency (Badan Meteorologi, Klimatologi, dan Geofisika, 2019). These comprised of information on wind, and waves from January 2008 to February 2018. Furthermore, data processing was performed with various software to create a vectorial map of the research position, and Table 1 shows the visual display of descriptive statistics used.

The wind and current data were downloaded from the Windwaves-05 software. The Windwave 05 software developed by Badan Meteorologi, Klimatologi, dan Geofisika (BMKG), where data were taken from the World Meteorological Organization, and consequently processed with MS Excel to obtain a visual display of descriptive statistics. In addition, the wind and wave rose diagrams were obtained using WRPlot ${ }^{\circledR}$, while wind and wave map layouts were processed with generic mapping tools (GMT). 
Figure 1 shows the research sites situated at part of the Java Sea, and it has a geographical extent of latitude $6^{\circ} 82^{\prime} 49^{\prime \prime}-7^{\circ} 18^{\prime} 30^{\prime \prime} \mathrm{S}$ and longitude $113^{\circ} 95^{\prime} 17^{\prime \prime}-115^{\circ}$ 30’34 “E.

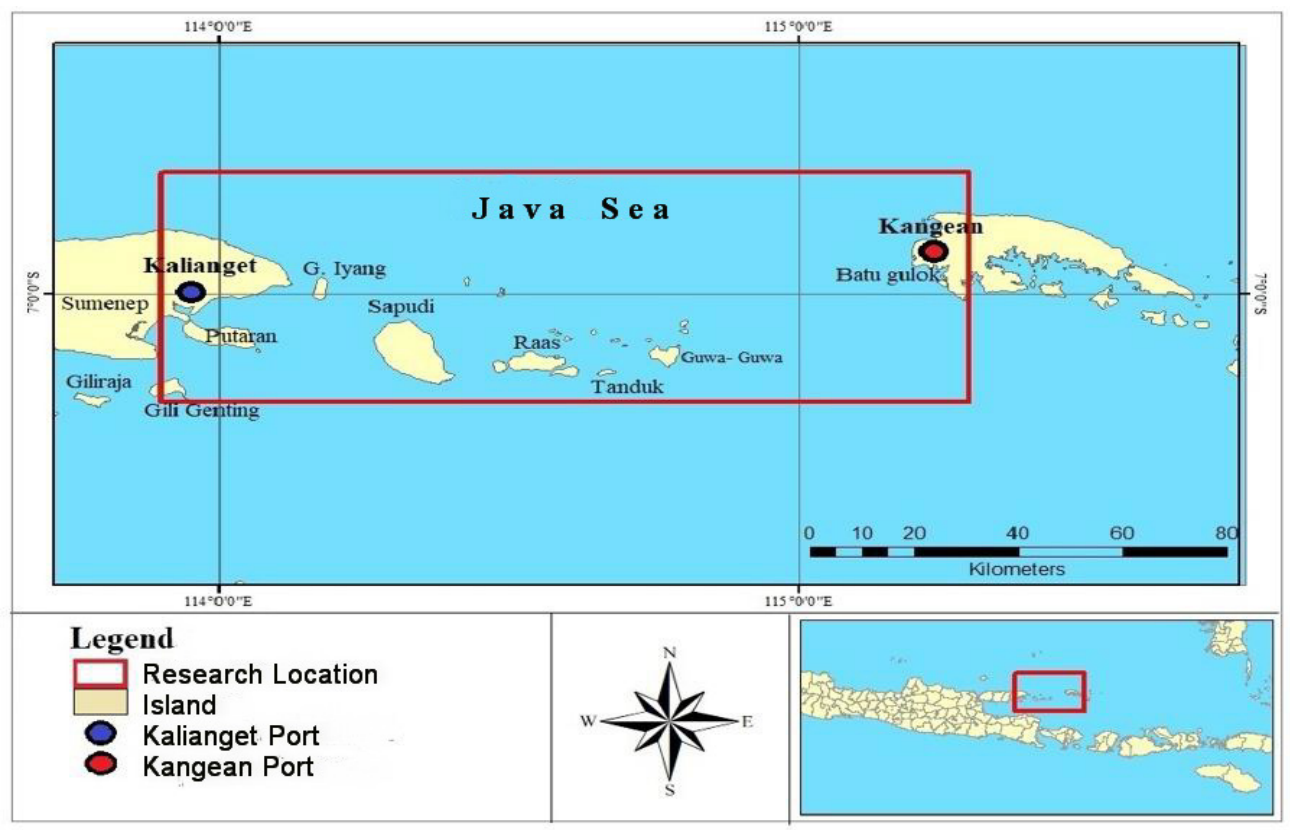

Figure 1. Research location in the Kalianget-Kangean cruise channel

Table 1

Software and usability as a research tool

\begin{tabular}{ll}
\hline Software & Function \\
\hline Google Earth & Make research position \\
Matlab & Processing data, making charts and rose diagrams \\
GMT & Make outputs of wind and wave maps \\
Microsoft excel & Data processing and making chart of descriptive statistical \\
WRPlot & Processing of wind and wave roses \\
Windwave-05 & Marine meteorological information \\
\hline
\end{tabular}

The safety of ferry cruise on the Kalianget-Bawean channel is evaluated at the Badan Meteorologi, Klimatologi, dan Geofisika (2019) by analyzing the weekly wind and wave data. This was performed every 6 hours daily, at 00:00, 06:00, 12:00, 18:00 from December 2017, January, and February 2018. The outcome is then processed with Matlab, and further by MS Excel to create a visual display. Subsequently, the information obtained is processed using GMT to create a map layout, to help predict the cruise's safety. 
Table 2 shows the comparison of wind speed and wave height results of the subsequent data analysis against wind and wave risk matrix for cruise safety (Badan Meteorologi, Klimatologi, dan Geofisika, 2018). This assessment is issued by BMKG, with the following conditions stipulated for ferries:

Table 2

Wind and wave risk matrix for cruise safety

\begin{tabular}{lcc}
\hline Level of Risks & & Ferry \\
\hline Very Safe (VS) & Wind & $<11 \mathrm{Knot}$ \\
& Wave & $<1.25 \mathrm{~m}$ \\
Safe (S) & Wind & $11-15 \mathrm{Knot}$ \\
& Wave & $1.25-2.0 \mathrm{~m}$ \\
Less Dangerous (LD) & Wind & $15-21 \mathrm{Knot}$ \\
& Wave & $2.0-2.5 \mathrm{~m}$ \\
Dangerous (D) & Wind & $>21 \mathrm{Knot}$ \\
& Wave & $>2.5 \mathrm{~m}$ \\
\hline
\end{tabular}

Sources. Badan Meteorologi, Klimatologi, dan Geofisika (2018)

\section{RESULTS AND DISCUSSION}

\section{Wind Characteristics 2008-2017}

Figure 2 shows the results of 10 -year wind patterns (2008-2017) analysis, which indicates the fluctuations of average speed between two peaks and two valleys. This phenomenon signifies the occurrence of an increase during the main season: west and east spaced by the transition period indicated by the valleys between. Furthermore, the average seasonal wind speed denotes slightly higher winds in the east season (June-September) compared to the west (December-March).

The average of $<15$ knots is considered a safe cruise status throughout the season. However, it is important to prioritize vigilance at the possibility of maximum values measuring nearly 30 knots, which is frequently observed in January through February. Furthermore, a sharp decline to below 20 knots is observed in March and is followed by a steady decrease between April-May. The wind speed tends to increase again at the inception of the east season in May, and peaks in August at $>21$ knots. This is considered a "dangerous" status for ferry before a subsequent decline to touch the nadir at the end of a Transition Season (November). Therefore, another rise is detected in December, indicating the inception of western season.

The wind pattern analysis in the west season during the strongest speed period in 2008-2017 shows a steady blow from the west. This dominates nearly $40 \%$ of the event 


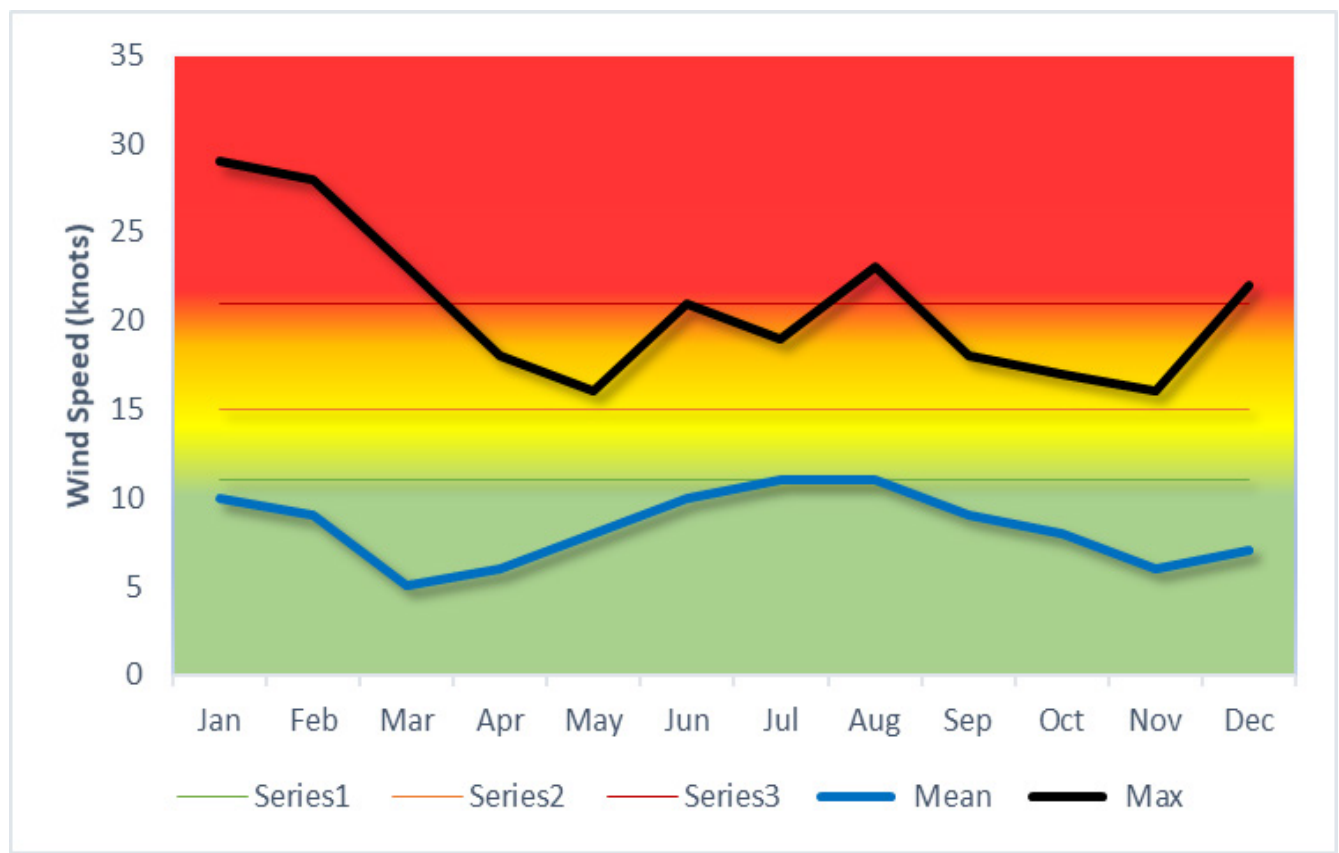

Figure 2. Monthly fluctuations in wind speeds during 2008-2017 confirm the high wind speeds in the west and east monsoons, as well as the weakening wind speeds during the transition periods.

frequency at the inception in December, followed by the $20 \%$ contributed by northwest wind. The rest sources blow from all directions at $<10 \%$. The dominant wind (38\%) blows at 4-8 knots during December, followed by $2-4$ knots (33.4\%). In addition, the maximum speed recorded was at 20-24 knots, despite the very small frequency $(0.5 \%)$ (Figure 3 : Dec). The peak is reached a month later and is indicated by the strengthened stability of the western wind, as shown in Figure 3. Moreover, January is characterized by $\sim 65 \%$ with a maximum of $28-32$ knots $(0.4 \%)$, although the dominant wind blows at speeds of 8-12 knots $(23.4 \%)$ and 5-8 knots $(22.3 \%)$. The west season subsequently weakened in February after attaining the peak, despite the persistence of the dominant source from the west. The value at this point was $<50 \%$, with a top speed of $24-26$ knots $(1.7 \%)$, although $4-8$ knots (29.4\%) was dominant (Figure 3: Feb).

\section{Wave Characteristics of 2008-2017}

The wave pattern was like the wind between 2008-2017, as evidenced by the two peaks observed, marking the highest values in the west and east season. Figure 4 shows the simultaneous presence of two valleys indicating low waves in the transition periods, observed at the beginning and end of each year. Moreover, the average wave height records 
all year round was generally below $2 \mathrm{~m}$ (except in July), and cruising along the KaliangetKangean channel is considered safe from this perspective. However, the maximum wave height recorded confirms the presence of very significant waves in the west season, which peaked in January at $6.7 \mathrm{~m}$. The highest values recorded in February was slightly reduced at $5 \mathrm{~m}$. Prior to attaining the peak in January, the maximum height recorded in December was $3.90 \mathrm{~m}$. Hence, there is a prohibition for Kalianget-Kangean route delivery in the west season because the greatest wave height value is $>2.5 \mathrm{~m}$.

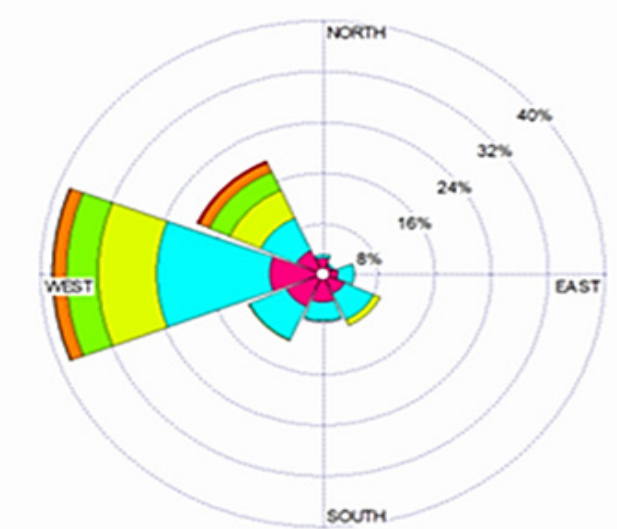

\section{DES}

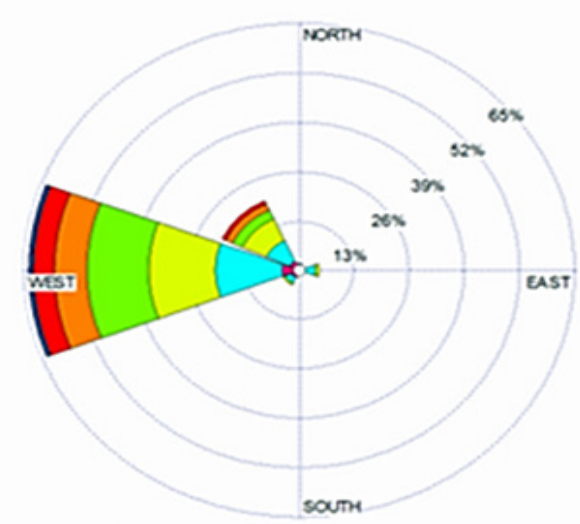

JAN

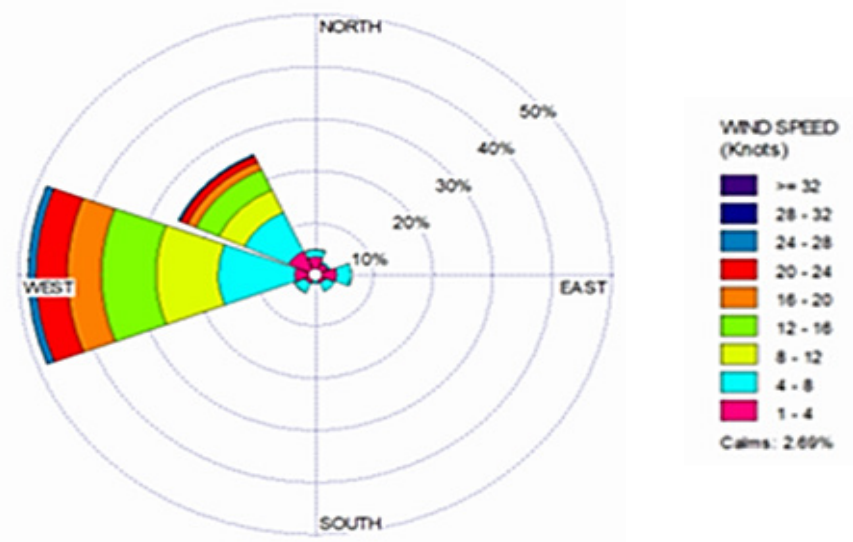

\section{FEB}

Figure 3. Wind speed patterns during December-February representing the west season 2008-2017 which shows the steady wind from the west 


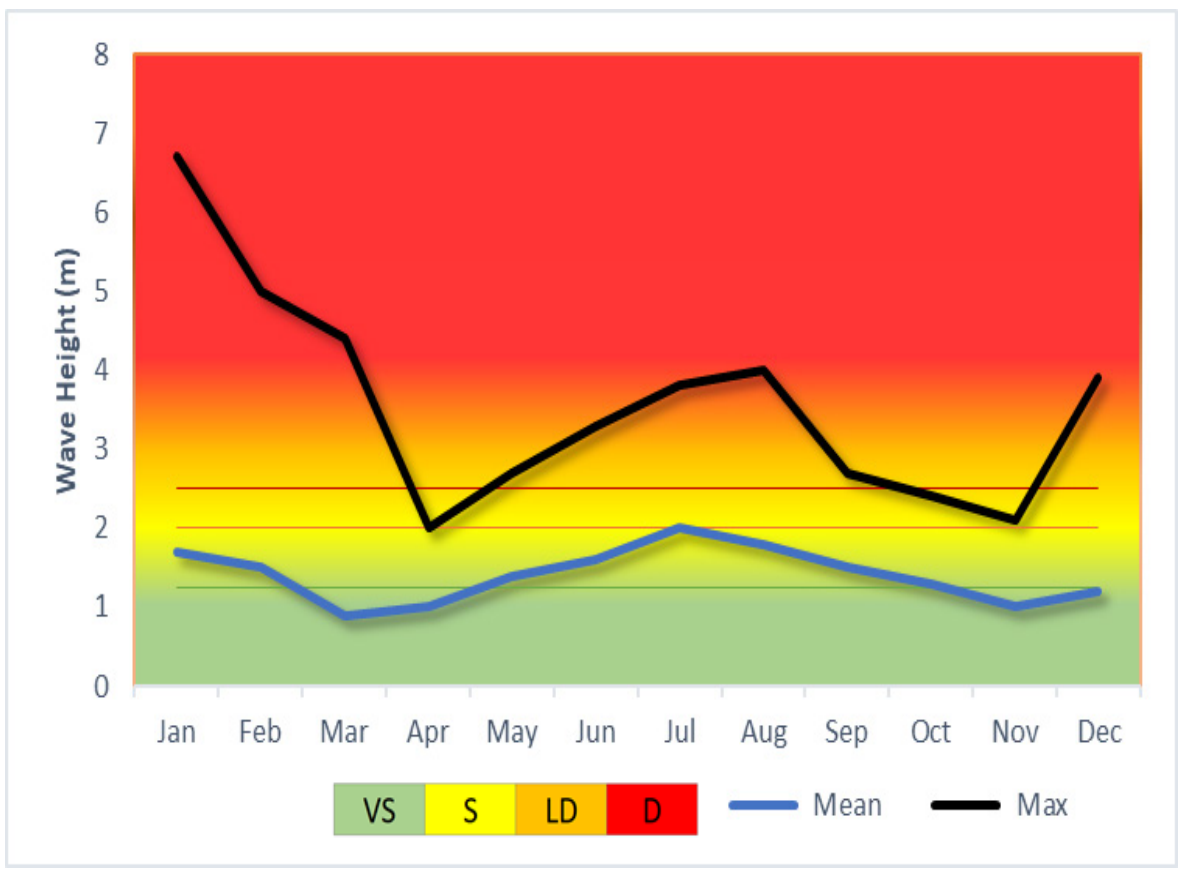

Figure 4. Monthly fluctuation in wave height during 2007-2018 confirms the increased wave height in the west and east seasons interspersed with low waves in the early and late year transition seasons

The transition season at the beginning of a year in March is marked by lower wave heights up to nadir $2.0 \mathrm{~m}$ observed in April. Furthermore, the values reported during the eastern season in May increased again and peaked in August, although a maximum of $4 \mathrm{~m}$ was attained. The results showed a subsequent decline to $2.1 \mathrm{~m}$ in November.

In addition, over 55\% of the waves recorded in December were 1-2 $\mathrm{m}$ high, and Figure 5 showed the highest value of 3-4 $\mathrm{m} \mathrm{2.7 \%}$. The predominant movement ensues from the south $(<50 \%)$ and northwest $(>30 \%)$ at the end of the year (Figure 5: Dec). Despite the dominance of 1-2 $\mathrm{m}$ high waves, the frequency is slightly reduced (47.5\%). This relatively lower value is accompanied by an increase in the highest attainable wave to 5-6 $\mathrm{m}(0.4 \%)$ and then $6-7 \mathrm{~m}(0.3 \%)$. The direction of flow is observed to be from the northwest $(\sim 45 \%)$. Despite the high level recorded from the south, the frequency was observed to be $<25 \%$, which is like the western waves. These conditions mark wave maturity in the west season, which peaks in January (Figure 5: Jan), followed by a weaker disposition in Feb, although the data obtained confirm the dominance of northwest waves $(<40 \%)$. Furthermore, there was a subsequent decline in the maximum height to $4-5 \mathrm{~m}(3.9 \%)$, leading to an increase in the wave region of $1-2 \mathrm{~m}$ to $40.7 \%$. 

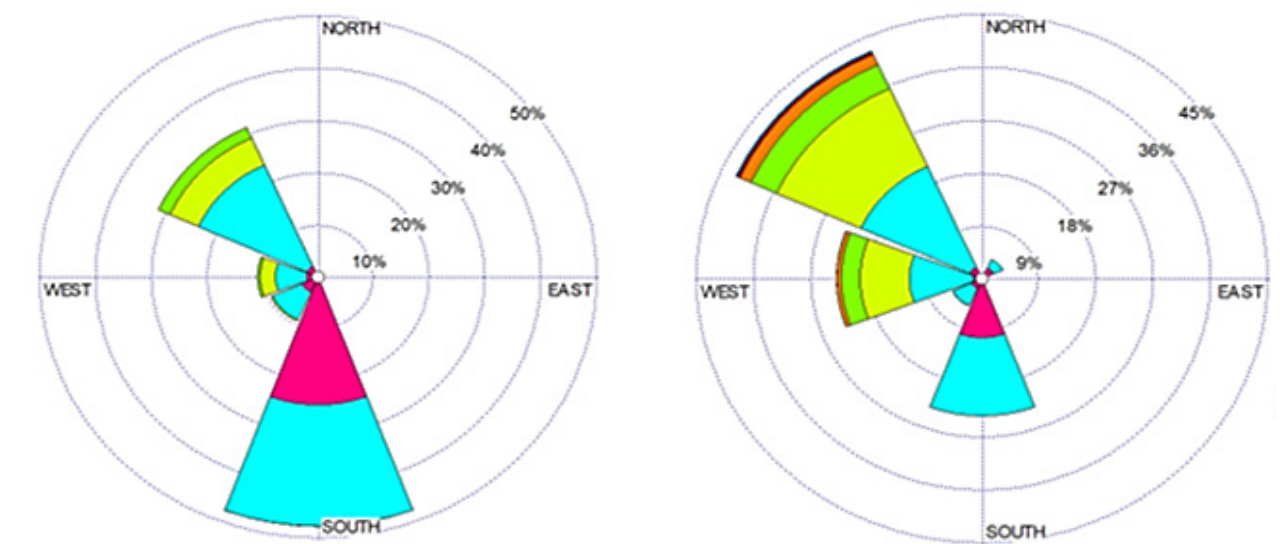

\section{DES}

\section{JAN}

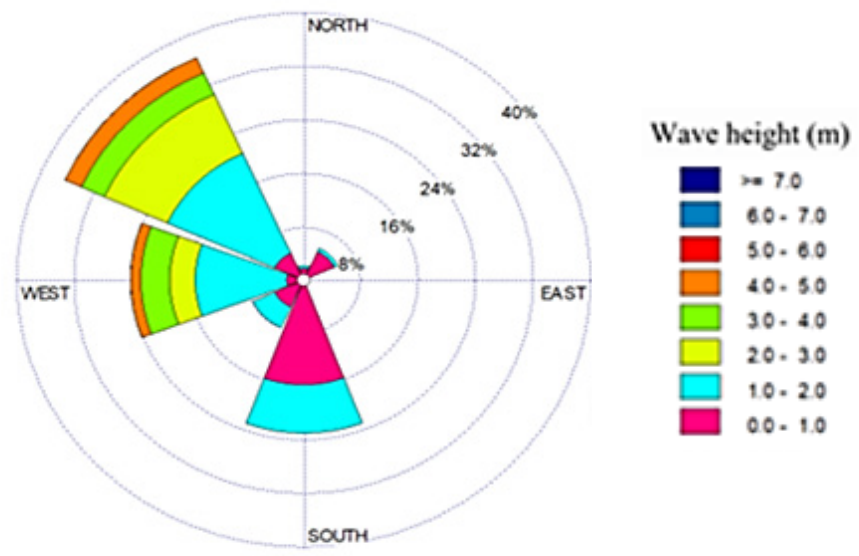

\section{FEB}

Figure 5. Wave height patterns during December-February representing the west season for the period 20082017. In general, the dominance of waves moves from the northwest

\section{Wind Characteristics from December 2017 to January-February 20018}

The weekly wind patterns at the peak of the west season from December 2017 to February 26, 2018 were analyzed. Figure 6 indicates the occurrence of two peaks and two valleys on the chart for wind speed. The average velocity fluctuates with a pattern like the maximum wind speed, where the peak of 13 knots was reached during the first fluctuation on December 
19-25, although a maximum of 22 knots was also recorded. Furthermore, speeds exceeding 21 knots in this time are considered dangerous for cruise in the Kalianget-Kangean route.

The first peak is followed by more slower winds to attain an average and maximum speed of nadir of $4 \mathrm{~m}$ and $7 \mathrm{~m}$ respectively on January 2-8, 2018. In addition, these conditions are considered relatively safe. This is followed by further wind reinforcement to maximum values of up to 25 knots and are considered dangerous to sail on January 2329,2018 . In addition, these huge values $>20$ knots were recorded for the next two weeks and was followed by a decline to 11 knots. Hence, the waters were reconsidered as safe for cruise activities.

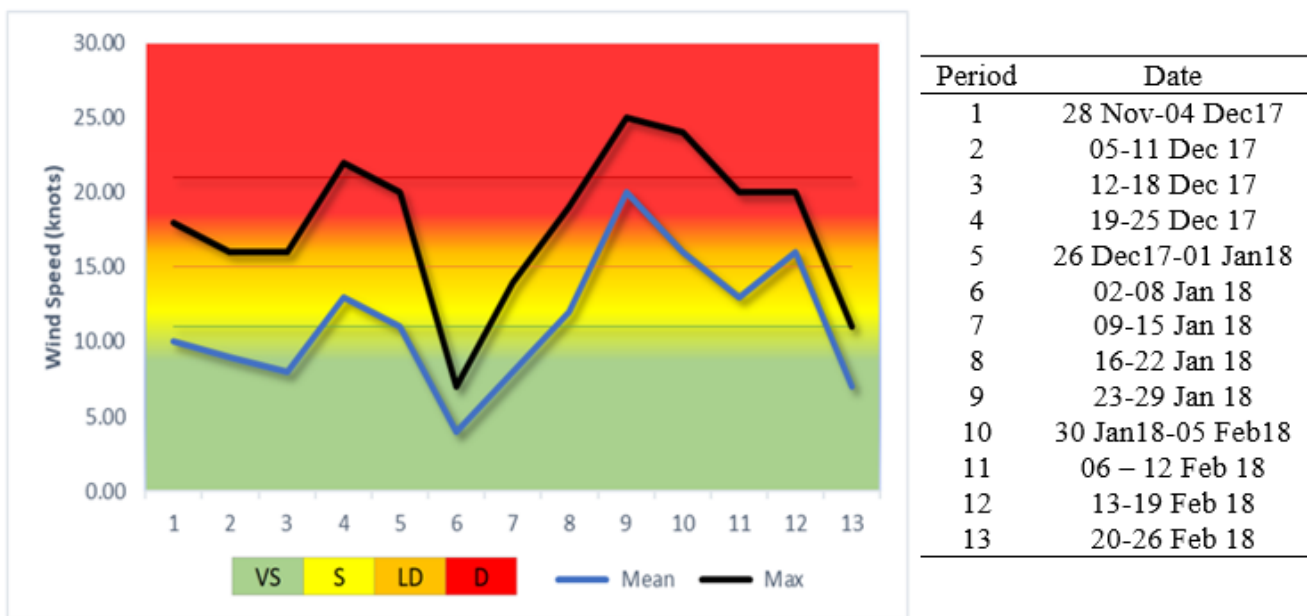

Figure 6. Weekly fluctuations in wind speed during November 2017- February 2018 which represent the peak of the west season

The illustration of various wind conditions and the risk level at the Kalianget-Kangean cruise route was performed by extracting data pertaining to wind patterns on January 4 at 12.00, January 15 at 18.00, January 17 at 17.00 and January 26, 2018 at 03.00 . These were respectively shown in Figure 7a through to Figure $7 \mathrm{~d}$.

Specifically, a maximum wind speed of 6-8 knots were recorded on January 4, 2018 at 12.00 , and the Kalianget waters alongside the surrounding areas of Kangean Island were assessed to be in a very safe and sailable condition (Figure $7 \mathrm{a}$ ). Figure $7 \mathrm{~b}$ shows a highest range of 10-15 knots on January 15 at 18:00, and the areas were considered safe for navigation. Figure 7c shows an increase to dangerous levels two days later at 17:00, in the Kalianget-Kangean cruise route to 15-20 knots. This phenomenon was observed particularly in the waters of Sapudi, Raas and Tanduk Islands, as well as around Kangean. Furthermore, all routes were classified as unsafe for navigation on January 26, 2018 at 
03.00, due to the maximum speed values measured, which reached 20-25 knots, as shown in Figure $7 d$.

\section{Wave Characteristics from December 2017 to February 2018}

Similar to wind speed, Figure 8 showed the weekly fluctuations in wave height during the 2018 west season, as indicated by two peaks and two valley wave. After the peaks were reached on December 6-11, with average and maximum wave heights of $0.61 \mathrm{~m}$ and 1.09 $\mathrm{m}$, respectively, there was a consequent elevation to values exceeding $2.5 \mathrm{~m}$.

Nugraha et al. (2013) also realized that the wave height in the west season could be between $2-4.5$ meters. This phenomenon was considered dangerous for cruise. Furthermore, $3.3 \mathrm{~m}$ was determined as the peak wave height between December 19-25, 2017, while the average values were estimated to be in a safe cruise condition, at $1.8 \mathrm{~m}$ $(<2 \mathrm{~m})$.

Subsequently, there was a decline in wave height, where the average and maximum values recorded on January 2-8, 2018 were below $1.5 \mathrm{~m}$. Therefore, higher levels, respectively at $2.73 \mathrm{~m}$ and $3.84 \mathrm{~m}$ were observed on January 23-29, 2018, and further considered as dangerous for cruise. These values were above the $2.50 \mathrm{~m}$ threshold were maintained up to the period of 13-19 February 2018. Subsequently, weaker waves emerged to average and maximum values of $0.31 \mathrm{~m}$ and $0.70 \mathrm{~m}$, respectively in February 20-26, 2018.

The risk levels are illustrated in relation to the varying wave conditions on the Kalianget-Kangean route by assessing the patterns recorded on 2 January 2018 at 12.00, 15 January 2018 at 21.00, 16 January 2018 at 21.00 and 25 January 2018 at 21.00. These were respectively shown in Figure 9a through to Figure 9d.

The waters at Kalianget and the Kangean archipelago, as well as the surroundings were in a very safe condition for navigation on January 2, 2018 at 12.00. This was due to the wave height of $\sim 0.5 \mathrm{~m}$ measured, as observed in Figure $9 \mathrm{a}$. In addition, the recording on January 15,2018 at 21:00 was determined to be harmless for cruise from Kalianget to Sapudi Island, at $<2 \mathrm{~m}$. However, there was an increase to dangerous level $(2-2.5 \mathrm{~m})$ on the consequent route to Kangean, as Figure $9 \mathrm{~b}$ showed values $>2.5 \mathrm{~m}$ in the northern waters of this Island. The waves recorded appear weakened at 21.00 on the next day, as shown in Figure 9c. In addition, the conditions were assumed to be very safe for navigation from the waters of Kalianget to Raas Island. The area around Tanduk Island was considered dangerous for sailing, as well as in areas further east approaching Kangean Island. Moreover, there was a drop to $<2 \mathrm{~m}$ at zones around the Kangean port and is further classified safe. Figure 9d shows the situation from Kalianget harbor to Sapudi Island waters as very safe $(<2 \mathrm{~m})$ on January 25, 2018 at 21:00. However, dangerous levels reaching $2.5 \mathrm{~m}$ were observed towards eastern, and approaching the waters of Raas Island. In addition, heights $>2.5 \mathrm{~m}$ 


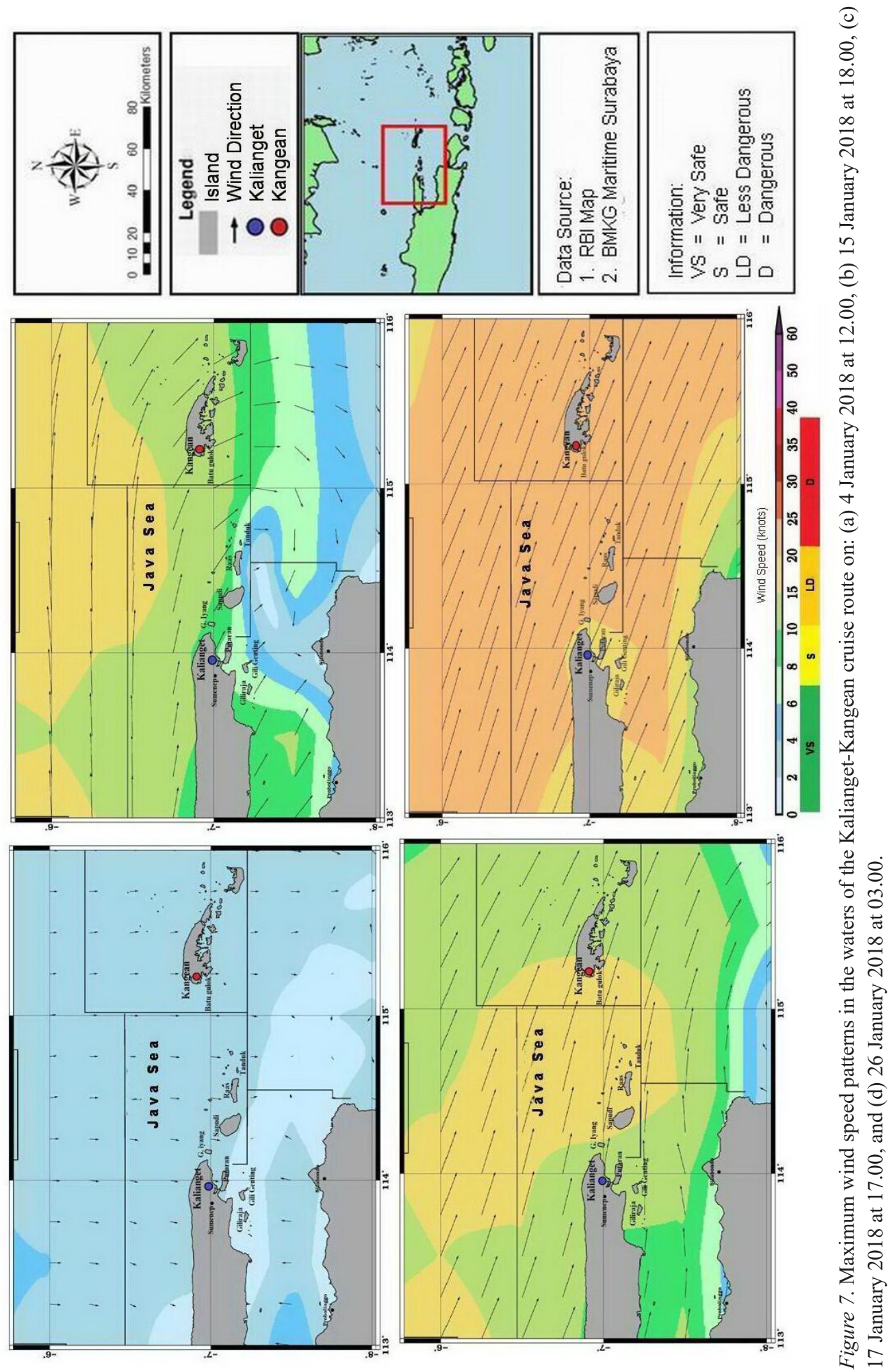




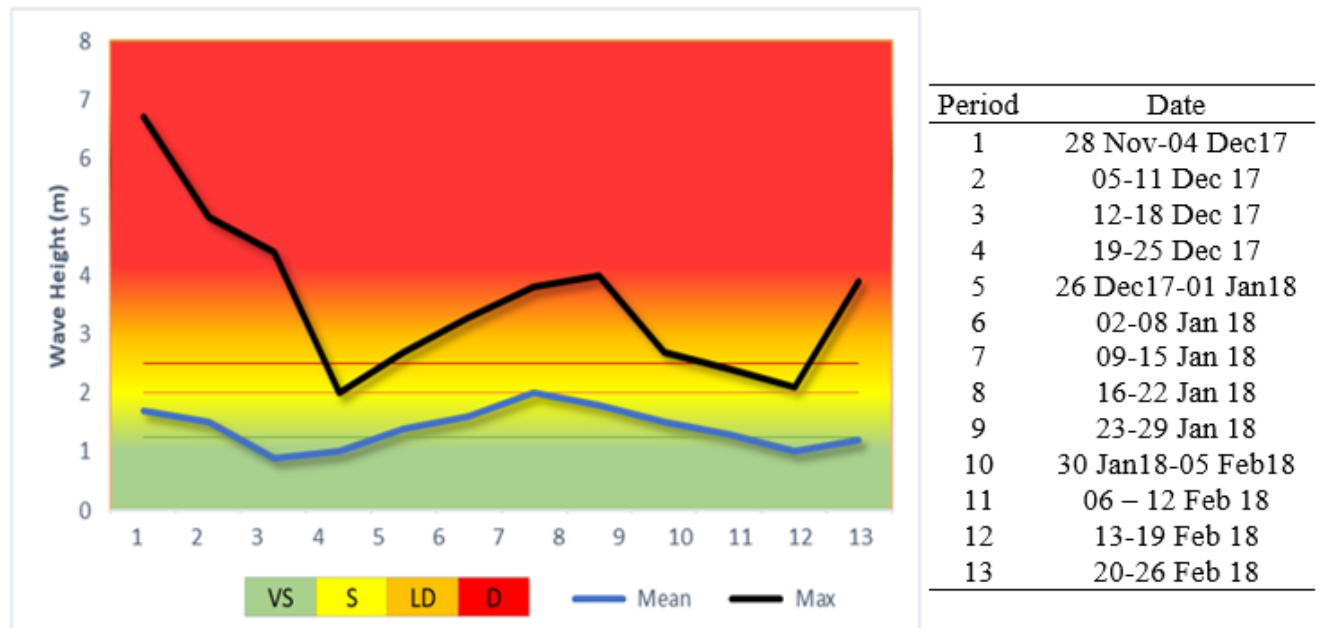

Figure 8. Weekly wave height fluctuations during November 2017-February 2018 which represent the peak of the west season

were observed further east in the sea before the Kangean waters, which potentially reaches $5 \mathrm{~m}$, although the consequent approach towards the Kangean port showed another decline to $<2 \mathrm{~m}$.

The wind and wave conditions in waters between Kalianget and Kangean moved steadily from northwest-west. This condition reflects the strong influence of (western) season, particularly at study sites situated at parts of the Java Sea. In addition, the west monsoon is characterized by both resilient blows in the northwest-west direction, as well as strong winds and high waves, in contrast with the monsoon season, which features relatively weak and unstable airstreams.

Wind-generated surface gravity waves occur everywhere in the oceans and play a primordial role in the oceans in the dynamics of the sea-land-atmosphere interface. In particular, sea surface wind waves fluctuate over a time span from a few seconds to several hours (Guillaume, et al. 2011). The waves are a combination of local sea-winds and large waves originating from a distant hurricane. Waves are most commonly caused by wind. Wind-driven waves, or surface waves, are created by the friction between wind and surface water. As wind blows across the surface of the ocean or a lake, the continual disturbance creates a wave crest (National Oceanic and Atmospheric Administration, 2021).

The size of the waves generated by the wind depends on the speed and duration of the wind, as well as the fetch which is the open water rapids where the wind blows. In addition, the depth of the sea also plays a role, because it is difficult to produce large waves in shallow waters. The invasion of the inter-tropical convergence zone (ITCZ) to the north or south due to the asymmetry of the continents of Eurasia and Australia caused a monsoon which 


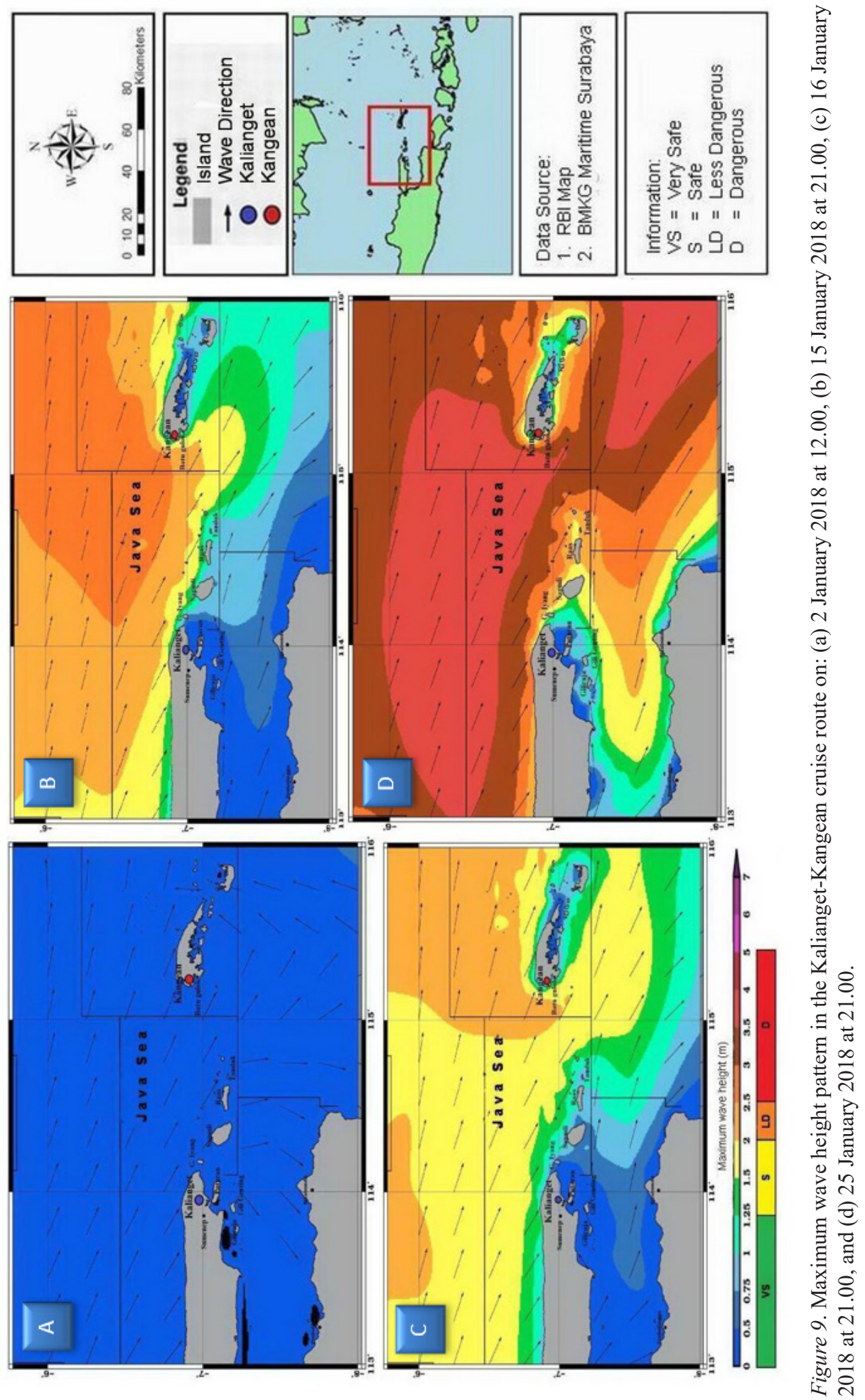


led to a wet (rainy) and dry (drought) period (Yamanaka, 2016). Monsoon, which is the 'Major Regime of Seasonal Wind Reversal,' is influenced by countries in Southeast Asia, including Indonesia as a maritime continent (Khan, 2020). These results also demonstrate the tendency to cause elevation in the wave height of waters between Tanduk and Kangean Islands. Furthermore, this phenomenon is possible through the effect of bathymetry depth as well as the incidence of narrowing on the north-south side of waters investigated. The silting effects around Kalianget and Kangean seaports are debilitating. Hence, the surrounding wave conditions are considered relatively safe for cruise.

Therefore, changes in surface wind speed and wave height may dramatically affect coastal communities (Ranasinghe, 2016), as well as offshore operations (Bitner-Gregersen et al. 2018).

\section{CONCLUSIONS}

The wind and wave characteristics between 2008 and 2017 generally form two peaks per annum and are known to mark the main seasons (west and east). Also, two valleys were observed in the middle, which further denotes the transition periods. The wind speed and wave height tend to generally occur below the danger threshold ( $<10$ knots and $<2 \mathrm{~m}$ ). However, there are exceptions in the west season, especially in January, featuring significant peak values during periods of strengthened wind speed and wave height with a steady blow. The maximum levels recorded reached 29 knots and $6.7 \mathrm{~m}$, respectively.

The weekly wind and wave conditions during December 2017 to February 2018 were relatively safe for sailing. Meanwhile, extreme conditions observed in January 23-29, 2018 were characterized by a maximum value of 25 knots and $3.8 \mathrm{~m}$, respectively, and further considered as dangerous.

The Kalianget-Kangean cruise channel is relatively safe, except in the time span of the west season, known to extend from December to February. This period features wind speeds exceeding 21 knots, with wave height reaching $2.5 \mathrm{~m}$, and the route was therefore determined to be dangerous in the west season.

\section{ACKNOWLEDGMENTS}

The authors gratefully acknowledge Professor Supartono for his invaluable inspiration. This research was supported by Hang Tuah University, Surabaya, Indonesia.

\section{REFERENCES}

Aji, D. R. (2015). Analisa karakteristik kecepatan angin dan tinggi gelombang menggunakan data satelit altimetri [Analysis of wind speed characteristics and wave height using altimetry satellite data]. Journal of Geodesy and Geomatics, 11(1), 75-78. http://dx.doi.org/10.12962/ j24423998.v11i1.1102

Arisandi, A., Tamam B., \& Fauzan, A. (2018). Coral reef profile of Kangean Island, Sumenep District, Indonesia. Jurnal Ilmiah Perikanan dan Kelautan, 10(2), 104-111. http://dx.doi.org/10.20473/jipk.v10i2.10516 
Badan Meteorologi, Klimatologi, dan Geofisika. (2019). Data angin tahunan 2008-2017 Sumenep, Jawa Timur, Indonesia [Annual wind data 2008-2017 Sumenep, East Java, Indonesia]. Author.

Badan Meteorologi, Klimatologi, dan Geofisika. (2018). Saran keselamatan pelayaran [Recommendation for cruise safety]. Retrieved February 26, 2021, from http://maritim.bmkg.go.id

Bitner-Gregersen, E. M., Vanem E., Gramstad, O., Hørte, T., Aarnes, O. J., Reistad, M., Breivik, Ø., Magnusson, A. K., \& Natvig, B. (2018). Climate change and safe design of ship structures. Ocean Engineering, 149, 226-237. https://doi.org/10.1016/j.oceaneng.2017.12.023.

Faqih, A. (2014). Prospek pengembangan potensi sumberdaya kelautan kepulauan Sumenep Madura [Prospect of marine resources potential development in Sumenep Madura Islands]. Universitas Brawijaya Press.

Guillaume, D., Angélique, M., Fabrice, A., Xavier, B., Déborah, I., \& Rafael, A. (2011). The contribution of wind-generated waves to coastal sea-level changes. Surveys in Geophysics, 40(6), 1563-1601. https:// doi.org/10.1007/s10712-019-09557-5

Khan, M. S. A. (2020). Climate change effect on southeast Asia's monsoon rainfall. International Journal of Advance Scientific Research and Engineering Trends, 5(9), 118-123.

Muhsoni, F. F. (2015). Pemanfaatan citra satelit LDCM untuk pemetaan kerapatan tajuk mangrove dan terumbu karang [Utilization of LDCM satellite imagery for mapping of mangrove and coral reef canopy density]. In Prosiding Seminar Perikanan dan Kelautan, (pp. 601-609). UTM Press.

National Oceanic and Atmospheric Administration. (2021). Why does the ocean have waves? Retrieved February 26, 2021, from https:/oceanservice.noaa.gov/facts/wavesinocean.html

Nugraha, W. A, Hidayah, Z., \& Insafitri. (2013). Developing coral reef conservation zones in the Kangean Archipelago, Indonesia. SEAMO SEARCA.

Ranasinghe, R. (2016). Assessing climate change impacts on open sandy coasts: A review. Earth-Science Reviews, 160, 320-332. https://doi.org/10.1016/j.earscirev.2016.07.011.

Rini, D. A. S., Pratikto, W. A., \& Sambodo, K. (2015). Identifikasi potensi kawasan sumberdaya Pulau Kangean Kabupaten Sumenep Madura sebagai kawasan wisata bahari [Identification of the potential of the Kangean Island resource area in Sumenep Madura Regency as a marine tourism area]. Indonesian Journal of Marine Science and Technology, 8(2), 60-70. https://doi.org/10.21107/jk.v8i2.814

Sandino, L. A., Bejar M., Kondak, K., \& Ollero, A. (2016). Multi-sensor data fusion for a tethered unmanned helicopter using a square-root unscented Kalman filter. Unmanned Systems, 4(4), 273-287. https://doi. org/10.1142/ S2301385016500114

Scotta, D., \& Lemieux, C. (2010). Weather and climate information for tourism. Procedia Environmental Sciences, 1(2010), 146-183. https://doi.org/ 10.1016/j.proenv.2010.09.011

Slamet, H. D. (2020). Kapal kangean tak beroperasi akibat cuaca buruk [Kangean ship not operating due to bad weather]. PortalMadura. Retrieved February 26, 2021, from https://portalmadura.com/kapal-kekangean-tak-beroperasi-akibat-cuaca-buruk-217429/

Yamanaka, M. D. (2016). Physical climatology of Indonesian Maritime Continent: An outline to comprehend observational studies. Atmospheric Research, 178-179(2016), 231-259. 